\title{
The impact of distress experienced during pregnancy on prenatal attachment
}

\author{
Anayit Margirit Coşkun (iD, Gülşen Okcu (D), Sedef Arslan \\ Nursing Department, Faculty of Health Sciences, Bezmialem Vakıf University, İstanbul, Turkey
}

\begin{abstract}
Objective: To determine the impact of distress experienced during pregnancy on prenatal attachment.

Methods: This descriptive and cross-sectional study was conducted with 370 pregnant women who admitted to the Clinic of Gynecology and Obstetrics of Faculty of Medicine of a Foundation University between March and July 2018. The data were obtained by using introductory information form, prenatal attachment scale and prenatal distress scale. Frequency and percentage distribution, mean values, Kruskal-Wallis and Mann-Whitney U tests and Spearman's correlation analysis were used for the analysis of the data.

Results: Of the pregnant women, $82.9 \%$ were in the age group of $18-35,36.8 \%$ were primigravida, $52.2 \%$ were always compatible with their partners, $70.8 \%$ got family support during this pregnancy and $30.2 \%$ had problems during this pregnancy. Mean scores of pregnant women in prenatal attachment scale and prenatal distress scale were $62.35 \pm 11.28$ and $10.26 \pm 5.18$, respectively. There was negatively weak and significantly advanced correlation between two mean scores.

Conclusion: Distress experienced during pregnancy affects prenatal attachment negatively. Prenatal distress level is significantly low in women who conceive intentionally and it is their first pregnancy, do not experience any problem and are always compatible with their partners. Planned pregnancy and compatibility with partner have a positive impact on prenatal attachment level.
\end{abstract}

Keywords: Prenatal attachment, distress, pregnancy.

\section{Introduction}

Pregnancy is a significant period that requires physiological, psychological and social changes in the lives of women. Women go through an adaptation process to pregnancy first and then the motherhood. While this process varies for every woman and her family, the problems related with adaptation to pregnancy, reactions and perceptions are also different. ${ }^{[1,2]}$

\section{Özet: Gebelikte distres durumunun prenatal bağlanmaya etkisi}

Amaç: Gebelikte yaşanan distres durumunun prenatal bağlanmaya etkisini belirlemektir.

Yöntem: Tanımlayıcı ve kesitsel türde gerçekleştirilen çalışma, Mart-Temmuz 2018 arasında bir Vakıf Üniversitesi Tip Fakültesi Hastanesi Kadın Hastalıkları ve Doğum Polikliniğine başvuran 370 gebe ile gerçekleştirildi. Veriler, tanıtıcı bilgi formu, prenatal bağlanma ölçeği ve prenatal distres ölçeği kullanılarak elde edildi. Verilerin analizinde, frekans ve yüzde dağılım, ortalama, KruskalWallis ve Mann-Whitney U testi ve Spearman korelasyon analizi kullanıldı.

Bulgular: Gebelerin \%82.9'u 18-35 yaş aralığında, \%36.8'i primigravida idi ve \%68.3'ü planlayarak gebe kalmış, \%52.2'si eşi ile her zaman uyumlu, \%70.8'i bu gebeliğinde aile desteği almış ve \%30.2'si bu gebeliğinde problem yaşamıştı. Gebelerin prenatal bağlanma ölçek puan ortalaması $62.35 \pm 11.28$, prenatal distres ölçek puan ortalaması $10.26 \pm 5.18$ idi. Her iki puan ortalamaları arasında negatif yönde zayıf ve ileri düzeyde anlamlı bir ilişki saptandı.

Sonuç: Gebelikte yaşanan distres durumu, prenatal bağlanmayı olumsuz yönde etkilemiştir. Planlayarak gebe kalan ve ilk gebeliği olan, gebelikte sorun yaşamayan ve eşi ile her zaman uyumlu olan kadınların prenatal distres düzeyi anlamlı derecede düşük bulunmuştur. Prenatal bağlanma düzeyine, planlı gebe kalma ve eşi ile uyumlu olma durumu olumlu yönde etkili olmuştur.

Anahtar sözcükler: Prenatal bağlanma, distres, gebelik.

The communication between expectant mother and baby during pregnancy is called "prenatal attachment". Today, the importance of prenatal attachment process is emphasized for establishing the attachment between mother and newborn in a short time at postpartum period. Accepting physical changes and transferring positive feelings to fetus is the first foundation of the attachment. The process of attachment between pregnant woman and

Correspondence: Anayit Margirit Coşkun, PhD. Nursing Department, Faculty of Health Sciences, Bezmialem Vakıf University, Fatih, Istanbul, e-mail: coskunano@yahoo.com / Received: May 31, 2019; Accepted: July 10, 2019

Please cite this article as: Coşkun AM, Okcu G, Arslan S. The impact of distress experienced during pregnancy on prenatal attachment. Perinatal Journal 2019;27(2):49-55. doi:10.2399/prn.19.0272001 
fetus begins as of the moment when woman responds to pregnancy positively. Mother perceiving fetus as an individual, interacting with fetus and interpreting fetal characteristics are the most important points in the development of mother-fetus attachment. Supporting the adaptation of pregnant woman to her new role during this period, raising awareness on maternal-fetal attachment and noticing potential issue early will increase the life quality of expectant mother significantly. ${ }^{[3,4]}$

Although pregnancy is a condition giving happiness to woman and her family, it can be a great burden and the source of stress for female body. The diseases of women which already exist or develop during pregnancy and stressful conditions such as hospitalization complicate pregnancy process further. It is affected by many factors such as the adaptation of individual to the risky conditions during pregnancy, reactions from the immediate surroundings, her feelings, thoughts, impulses and desires, hospitalization and treatment processes, fetal health condition and the requirement of bed rest. During pregnancy, fetus is affected by the changes in maternal organism as well as pregnant woman. It is reported that risky pregnancies, problems such as stressful conditions during pregnancy, fetal health and growth affect the development negatively. ${ }^{[3,5]}$

In the literature, desiring and planning pregnancy, socioeconomic and cultural status of family, social support systems, health issues and stressful conditions during pregnancy, maternal age, educational and employment status, family type and the status of participating in childbirth classes etc. are highlighted among the factors affecting prenatal attachment level. ${ }^{[1,6]}$ In the studies conducted, it was found that the processes of adaptation to motherhood and attachment to newborn were rapid and postpartum depression levels were low in pregnant women who participated in childbirth class and actively participated in their own deliveries. It was also reported that working pregnant women have low levels of stress and anxiety and pregnant women with elementary family structure have higher attachment levels. ${ }^{[2,7-9]}$ Prenatal attachment levels were higher in primiparous pregnant women than multiparous pregnant women. ${ }^{[10]}$ In a study investigating prenatal attachment level and affecting factors in pregnant women with high risk, it was found that attachment level of pregnant women were moderately low, and educational status affected attachment in a direct proportion while age affected it in an inverse proportion. Furthermore, it was found that primigravida cases have higher prenatal attachment levels compared to multiparous cases and there was an inverse correlation between the number of children and prenatal attachment. ${ }^{[6]}$ Positive conditions such as compatible marriage relationship, desired and planned pregnancy and receiving social support from partner, family members and immediate surroundings facilitate the processes of attachment and adaptation to changes caused by pregnancy and risky conditions in particular. The studies show that the use of harmful substances such as cigarette, alcohol and drugs and the status of experiencing stress and depression related with parenthood are at a high level and mother-baby attachment is insufficient in unplanned and unintended pregnancies. ${ }^{[10-13]}$

Participating in antenatal training and childbirth classes may be effective for expectant mothers and fathers to have a healthy and happy pregnancy process. In this way, the process of adaptation to pregnancy and conscious preparation for parenthood become smooth and it is easier to manage negative conditions experienced during pregnancy and causing distress. Therefore, it is possible to support prenatal attachment process of pregnant woman and her partner. It is important to evaluate not only physical health needs but also psychosocial condition of pregnant woman and her family, raise awareness about parenthood and support maternal attachment process in the training programs managed by nurses and midwives. Some studies reported that extensive nursing care and training programs given through a holistic approach during prenatal period decrease the distress of pregnant woman and improve prenatal attachment. ${ }^{[1,2,14,15]}$

We conducted this study to determine the impact of distress experienced during pregnancy on prenatal attachment. We believe that the results obtained will enrich and support the nursing care and the content of antenatal training programs.

In line with this purpose, we sought answers for the questions below:

- What is the level of prenatal distress of pregnant women?

- Does the stress experienced during pregnancy affect prenatal attachment?

- Do some sociodemographic and obstetric characteristics causing stress during pregnancy affect prenatal attachment?

\section{Methods}

The population of this descriptive and cross-sectional study consisted of 10,000 pregnant women who were 18 
years old and above and who admitted to the Clinic of Gynecology and Obstetrics of Faculty of Medicine of a Foundation University between March and July 2018.

The sample of the research consisted of a total of 397 pregnant women who admitted to the clinic during the same period and were selected by random sampling method according to the following criteria. The number of samples was determined as 370 pregnant women considering the sample size table with $95 \%$ CI and \pm 0.05 margin of error.

The inclusion criteria were as below:

- Willingness to participate in the research

- Not having a psychiatric disease

- Speaking Turkish

- Data collection tools

Introductory information form developed according to the literature, prenatal attachment inventory and prenatal distress scale were used to collect research data. The consents of the participants were obtained for the use of scales.

Introductory information form: Sociodemographic and obstetric characteristics of the pregnant women were obtained by the form consisting of 21 questions prepared according to the literature. ${ }^{[16-20]}$

Prenatal attachment inventory (PAI): The scale, which was developed by Mary Muller in 1993 in order to describe thoughts, emotions and conditions of woman throughout the pregnancy and to determine fetal attachment level during prenatal period, consists of 21 items. In this four-point Likert type scale, the minimum and maximum scores are 21 and 84, relatively. As the score increases, the level of attachment level of pregnant woman increases as well. Yllmaz and Beji ${ }^{[3]}$ performed the validation and confidence check of the scale and they reported the coefficient of internal consistence 0.84 . In our study, we found the coefficient of internal consistence 0.77 .

Prenatal distress scale (PDS): The scale, which was developed in order to evaluate gestational stress, anxiety or concerns, was reorganized by Lobel in 2008 and a new version with 17 items was created. It was adapted into Turkish by Yüksel, Akın and Durnal ${ }^{[1]}$ in 2011 and its content validity was found $96 \%$ and Cronbach's alpha internal consistency coefficient was found 0.85 . In our study, Cronbach's alpha internal consistency coefficient was 0.80 . The Likert-type scale containing 17 items has options "None" (0), "Slightly" (1) and "Highly" (2) for being distressed, sorry or concerned at the time for each item. The distress score specific to the pregnancy experienced during gestational period is determined by combining the scores of each scale item, and minimum score is 0 while maximum score is 34 in the scale. The increase in the total score of the respondents is interpreted as the increase in the prenatal distress level perceived by pregnant women. The scale does not have a cutoff score.

For the ethic approval of the research, written approval was obtained from Ethics Committee of Bezmialem Vakıf University (Ethic approval no. 5-32; Date: 27.02 .2018 ) and the institution that the study will be conducted. Informed consents were obtained from the pregnant women participating in the research by informing them about the purpose of the research.

SPSS version 24.0 (SPSS Inc., Chicago, IL, USA) was used for the evaluation of the data. Frequency, percentage and mean values, Kruskal-Wallis and MannWhitney U tests and Spearman's correlation analysis were used for the analysis of the data. $\mathrm{p}<0.05$ was considered as significant.

\section{Limitations}

Since the sample was limited with a single center in Istanbul, we think that the results cannot be generalized and that conducting the research by descriptive method makes it impossible to make causative inferences.

\section{Results}

As seen in Table 1, the majority (82.9\%) of the pregnant women who participated in the research were in the age group of $18-35,81.4 \%$ of them had elementary family structure, $36.8 \%$ of them were primigravida, $68.3 \%$ of them had a planned pregnancy, $69.8 \%$ of them did not have any problem in this pregnancy and $70.8 \%$ got family support during this pregnancy. Of 120 pregnant women who had problems during the pregnancy, $42.5 \%$ (51 pregnant women) had gestational complications such as hyperemesis and the threats of miscarriage and premature birth, partial placenta previa, and mild preeclampsia etc., $22.5 \%$ (27 pregnant women) had health issues which complicate the pregnancy such as anemia, gestational diabetes, influenza, and $\mathrm{Rh}$ incompatibility etc., and 35\% (42 pregnant women) had both conditions (Table 1).

As seen in Table 2, mean scores of pregnant women for PAI and PDS were $62.35 \pm 11.28$ (range: $21-84$ ) and $10.26 \pm 5.18$ (range: $0-26$ ), respectively. According to this result, it was found that prenatal attachment perceived by 
Table 1. Some sociodemographic and obstetric characteristics of the pregnant women $(n=397)$.

\begin{tabular}{|c|c|c|c|}
\hline \multicolumn{2}{|c|}{ Sociodemographic and obstetric characteristics } & \multirow{2}{*}{$\begin{array}{c}\text { Number } \\
119\end{array}$} & \multirow{2}{*}{$\begin{array}{c}\% \\
30.0\end{array}$} \\
\hline Age & $18-26$ & & \\
\hline & $27-35$ & 210 & 52.9 \\
\hline & 36 years old and above & 68 & 17.1 \\
\hline \multirow[t]{5}{*}{ Educational level } & Literate & 10 & 2.5 \\
\hline & Primary school & 56 & 14.1 \\
\hline & Secondary school & 83 & 20.9 \\
\hline & High school & 137 & 34.5 \\
\hline & University and above & 111 & 28.0 \\
\hline \multirow[t]{3}{*}{ Family type } & Elementary & 323 & 81.4 \\
\hline & Extended & 71 & 17.9 \\
\hline & Fragmented & 3 & 0.7 \\
\hline \multirow{2}{*}{$\begin{array}{l}\text { Having problem during } \\
\text { this pregnancy }\end{array}$} & Available & 120 & 30.2 \\
\hline & Not available & 277 & 69.8 \\
\hline \multirow[t]{3}{*}{ Partner compatibility } & Always compatible & 207 & 52.2 \\
\hline & Compatible & 184 & 46.3 \\
\hline & Incompatible & 6 & 1.5 \\
\hline \multirow[t]{3}{*}{ Number of children } & None (primigravida) & 146 & 36.8 \\
\hline & $1-2$ & 194 & 48.9 \\
\hline & 3 and more & 57 & 14.3 \\
\hline \multirow{2}{*}{$\begin{array}{l}\text { Planning status of } \\
\text { this pregnancy }\end{array}$} & Planned & 271 & 68.3 \\
\hline & Unplanned & 126 & 31.7 \\
\hline \multirow{2}{*}{$\begin{array}{l}\text { Receiving family support } \\
\text { during pregnancy }\end{array}$} & Available & 281 & 70.8 \\
\hline & Not available & 116 & 29.2 \\
\hline
\end{tabular}

Table 2. Mean scores of prenatal attachment inventory (PAI) and prenatal distress scale (PDS) of the pregnant women.

\begin{tabular}{lccc} 
Scales & Minimum & Maximum & $\chi \pm$ SD* \\
PAl & 21 & 84 & $62.35 \pm 11.28$ \\
PDS & 0 & 26 & $10.26 \pm 5.18$ \\
\hline
\end{tabular}

${ }^{*} \chi \pm \mathrm{SD}=$ Mean \pm standard deviation.

Table 3. The correlation between the mean scores of prenatal attachment inventory (PAI) and prenatal distress scale (PDS) of the pregnant women.

\begin{tabular}{lcc} 
& PDS & PAI \\
PDÖ & $r=-0.002 *$ & $r=-0.002^{*}$ \\
PBÖ & \\
\hline
\end{tabular}

${ }^{*} p<0.001$

the pregnant women was "at a high level" and stress level of pregnant women was "slightly lower than moderate level".

It was shown in Table 3 that there was a negatively weak correlation between the mean scores of PAI and PDS $(\mathrm{r}<1)$. According to this result, as mean score of prenatal distress scale increased, in other words, as their stress levels increased, their mean scores of prenatal attachment decreased significantly.

It is shown in Table 4 that age did not affect PDS score but PAI scores of the pregnant women in the age group of 18-35 were much higher than the pregnant women who were above 35 years old and this was statistically significant at a higher level. This result was confirmed by intragroup comparisons. In terms of the number of children, mean PDS scores were significantly higher in primigravida women than those with 1-2 children and higher in those with 3 and more children than those in two other groups. Mean PDS scores were significantly higher in women with unplanned pregnancy than those with planned pregnancy and in women who had problems in this pregnancy than those who did not have any problem. It was found that mean PAI scores of women with planned pregnancy were significantly higher than those with unplanned pregnancy. In terms of compatibility with partner, mean PDS scores were lower in pregnant women in the group of "always compatible" compared to two other groups. The highest mean PDS score was seen in the pregnant women in the "incompatible" group. Mean PAI scores were higher in a statistically significant way in favor of the "always compatible" group.

\section{Discussion}

Issues experienced during pregnancy such as unplanned pregnancy, multiparity, pregnancy at an advanced age, partner incompatibility and not receiving support from the immediate surroundings, current health problems during pregnancy, hospitalization and/or bed rest need may be a stress reason and it also affects prenatal attachment process of the expectant mother negatively. ${ }^{[1-4]}$

In the post-graduate thesis study of Çobanlar Akkaş entitled "Compatibility between partners during pregnancy", the author reported that $80 \%$ of the pregnant women received support from their partners and families, and $73.3 \%$ of them had planned pregnancy. ${ }^{[17]}$ In the studies investigating similar issues, planned pregnancy rate exhibits a difference interval ranging from $68 \%$ to $80 \% .^{[5-7]}$ Our results for partner and family supports and planned pregnancy rate are consistent with the literature.

In parallel with our study, 2013 data of Turkey Demographic and Health Survey (TDHS) reported that the highest fertility rate according to the age is in the age group of $20-30 .^{[8]}$ 
Table 4. The comparison of the mean scores of prenatal attachment inventory (PAI) and prenatal distress scale (PDS) with the sociodemographic and obstetric characteristics of the pregnant women.

\begin{tabular}{|c|c|c|c|c|c|}
\hline Characteristics & & $\begin{array}{c}\text { PDS } \\
(\bar{\chi} \pm S S)\end{array}$ & $\begin{array}{c}\mathrm{KW}^{\dagger} / \mathrm{z}^{\ddagger} \text { and } \\
\mathrm{p} \text { value }\end{array}$ & $\begin{array}{c}\text { PAI } \\
(\overline{\bar{X}} \pm S S)\end{array}$ & $\begin{array}{c}\mathrm{KW}^{\dagger} / \mathbf{z}^{\ddagger} \text { and } \\
\mathbf{p} \text { value }\end{array}$ \\
\hline Age & $\begin{array}{l}18-26(n=119) \\
27-35(n=210) \\
36 \text { years old and above }(n=68)\end{array}$ & $\begin{array}{c}10.08 \pm 4.99 \\
10.59 \pm 5.37 \\
9.58 \pm 4.89\end{array}$ & $1.931^{\dagger} / 0.381$ & $\begin{array}{l}63.18 \pm 1.04 \\
63.50 \pm 11.09 \\
57.35 \pm 11.07\end{array}$ & $17.415^{\dagger} / 0.000 * * *$ \\
\hline Educational level & $\begin{array}{l}\text { Graduated from the primary school at least }(n=66) \\
\text { Graduated from the elementary school or above }(n=331)\end{array}$ & $\begin{array}{l}10.48 \pm 5.85 \\
10.22 \pm 5.04\end{array}$ & $0.007^{\ddagger} / 0.994$ & $\begin{array}{l}61.31 \pm 11.37 \\
62.56 \pm 11.26\end{array}$ & $0.737^{\ddagger} / 0.461$ \\
\hline Family type & $\begin{array}{l}\text { Elementary }(n=323) \\
\text { Extended }(n=71) \\
\text { Fragmented }(n=3)\end{array}$ & $\begin{array}{l}10.14 \pm 5.04 \\
10.56 \pm 5.73 \\
16.00 \pm 3.60\end{array}$ & $4.066^{\dagger} / 0.131$ & $\begin{array}{l}62.24 \pm 11.53 \\
63.25 \pm 10.00 \\
52.66 \pm 10.50\end{array}$ & $2.957^{\dagger} / 0.228$ \\
\hline Number of children & $\begin{array}{l}\text { None }(n=142) \\
1-2(n=197) \\
3 \text { and more }(n=58)\end{array}$ & $\begin{array}{c}9.90 \pm 5.04 \\
9.83 \pm 4.85 \\
12.62 \pm 5.99\end{array}$ & $10.384^{\dagger} / 0.006^{* *}$ & $\begin{array}{l}63.85 \pm 11.63 \\
61.75 \pm 10.88 \\
60.74 \pm 11.51\end{array}$ & $4.810^{\dagger} / 0.090$ \\
\hline $\begin{array}{l}\text { Planning status of } \\
\text { this pregnancy }\end{array}$ & $\begin{array}{l}\text { Planned }(n=271) \\
\text { Unplanned }(n=126)\end{array}$ & $\begin{array}{r}9.39 \pm 4.63 \\
12.14 \pm 5.79\end{array}$ & $4.285^{\ddagger} / 0.000^{* * *}$ & $\begin{array}{l}63.40 \pm 11.24 \\
60.20 \pm 11.07\end{array}$ & $7.031^{\ddagger} / 0.008^{*}$ \\
\hline Partner compatibility & $\begin{array}{l}\text { Always compatible }(n=207) \\
\text { Compatible }(n=184) \\
\text { Incompatible }(n=6)\end{array}$ & $\begin{array}{c}9.38 \pm 5.02 \\
11.12 \pm 5.13 \\
14.33 \pm 6.53\end{array}$ & $14.269+/ 0.001 * *$ & $\begin{array}{c}64.19 \pm 11.58 \\
60.44 \pm 10.67 \\
57.50 \pm 8.96\end{array}$ & $15.442^{\dagger} / 0.000 * * *$ \\
\hline $\begin{array}{l}\text { Having problem during } \\
\text { this pregnancy }\end{array}$ & $\begin{array}{l}\text { Available }(n=120) \\
\text { Not available }(n=277)\end{array}$ & $\begin{array}{c}11.82 \pm 4.98 \\
9.59 \pm 5.13\end{array}$ & $4.179 \ddagger / 0.000 * * *$ & $\begin{array}{l}62.80 \pm 11.36 \\
62.15 \pm 11.25\end{array}$ & $0.670^{\ddagger} / 0.503$ \\
\hline $\begin{array}{l}\text { Receiving family support } \\
\text { during pregnancy }\end{array}$ & $\begin{array}{l}\text { Available }(n=281) \\
\text { Yok }(n=116)\end{array}$ & $\begin{array}{l}10.37 \pm 5.20 \\
10.01 \pm 5.13\end{array}$ & $0.802^{\ddagger} / 0.423$ & $\begin{array}{l}62.92 \pm 10.87 \\
60.97 \pm 12.15\end{array}$ & $1.149 \ddagger / 0.251$ \\
\hline
\end{tabular}

$\bar{\chi}_{ \pm} \mathrm{SD}=$ Mean \pm standard deviation. $\mathrm{KW}^{+}$: Kruskal-Wallis test; $\mathrm{z}^{\ddagger}$ : Mann-Whitney $U$ test; ${ }^{*} \mathrm{p}<0.05 ;{ }^{* *} \mathrm{p}<0.01 ;{ }^{* * *} \mathrm{p}<0.001$.

In the study of Alan Dikmen and Çankaya, entitled as "The impact of maternal obesity on prenatal attachment", the authors reported that $46.6 \%$ of the women had problems during pregnancy and in parallel with this result, they stated that prenatal attachment rate was significantly low. ${ }^{[9]}$ The study of Erkal Aksoy et al., entitled as "Prenatal attachment in risky pregnancies and social support", reported similar results. In their study, the authors reported the rate of having a problem during pregnancy $48.8 \% .{ }^{[1]}$ Unlike these two studies, we found this rate $30.2 \%$ in our study and this difference can be explained by the fact that those studies were conducted on obese and risky pregnant groups.

In our study, the mean PAI and PDS scores were $62.35 \pm 11.28$ and $10.26 \pm 5.18$, relatively (Table 2). In the study of Yilmaz and Beji (2010), entitled as "Adapting prenatal attachment inventory into Turkish", mean PAI scores of 210 pregnant women who participated in the research was $60.7 \pm 10.1 .^{[3]}$ In similar studies reflecting our social characteristics, mean PAI scores of pregnant women were close to each other. In their study conducted on pregnancies with high risk, Bakır et al. ${ }^{[2]}$ found this rate $61.96 \pm 9.24$, Erkal Aksoy et al. ${ }^{[1]}$ found it 56.76 \pm 9.23 in their study conducted on risky pregnancies, and Alan Dikmen and Çankaya ${ }^{[9]}$ found it $61.24 \pm 0.49$ in their study about the impact of maternal obesity on prenatal attachment. In our study which was consistent with the literature, we found high level of prenatal attachment perceived by the pregnant women who participated in our research. ${ }^{[1-3,9]}$

As an answer to our first research question, we found in our study that the prenatal distress level of pregnant women was slightly lower than moderate level. In the study of Altınçelep, ${ }^{[10]}$ entitled as "Determining prenatal distress level of pregnant women", mean PDS scores of 522 pregnant women who participated in the research were at a low level $(9.88 \pm 4.79)$. This different rate may result from the characteristics of pregnant women, who participated in the relevant study, from the group which had fewer problems during the pregnancy $(10.26 \pm 5.18)$. Conversely, Yüksel et al. ${ }^{[11]}$ conducted a study, entitled "Adaptation of prenatal distress scale into Turkish and factor analysis", with 233 pregnant women, and they found mean PDS scores $12.03 \pm 5.61$. The distress level found in this study conducted with 370 pregnant women, who admitted to the clinic for routine antenatal checks and only $30.2 \%$ of whom expressed some small problems related with pregnancy, is consistent with the literature. $^{[10,11]}$

Our second research question is answered in Table 3, and we found a negatively weak correlation between the mean scores of PAI and PDS $(r<1)$. According to this 
finding, the perception of pregnancy and prenatal attachment of pregnant women, who experienced stress due to various reasons during pregnancy, were affected negatively. In their study, Abasi et al. ${ }^{[12]}$ found a correlation similar to our study and reported that there is a negatively significant correlation between gestational anxiety and prenatal attachment. Unlike our results, Topaç Tunçel and Kahyaoğlu Süt ${ }^{[13]}$ evaluated the prenatal depression and prenatal attachment during all three trimesters of 319 pregnant women that they monitored in their study. Within the scope of their data, they found that mean PDS scores of the participants decreased as the trimesters advanced although they were not at a significant level (1st trimester: 9.7 \pm 5.7 ; 2nd trimester: 9.2 \pm 5.2 ; 3rd trimester: $9.2 \pm 4.8$ ) while their mean PAI scores increased $(54.9 \pm 13.9,61.3 \pm 10.9$ and $64.1 \pm 11.1$, respectively), and the correlation was highly significant. Our study results were consistent with these data and we found that there is a negative correlation between stress level and prenatal attachment of pregnant women. ${ }^{[1,13]}$

We evaluated the answer of our last research question, "Do some sociodemographic and obstetric characteristics causing stress during pregnancy affect prenatal attachment?", in Table 4. In this regards, we found that age, fertility status, partner compatibility, planning pregnancy and having problems during pregnancy affect PDS and PAI scores. In harmony with our research data, Y1lmaz and Beji ${ }^{[3]}$ reported in their study that primiparous pregnant women have higher levels of prenatal attachment. In the same study, the authors found that women who conceived without any plan and being prepared have lower mean prenatal attachment scores but significantly higher mean prenatal distress scores.

In our study, we found that age did not affect PDS score but PAI scores of the pregnant women in the age group of 18-35 were much higher than the pregnant women who were above 35 years old and this was statistically significant at a higher level. Similar to our results, Elkin $^{[14]}$ found in their study investigating prenatal attachment level of pregnant women and the factors affecting this level that $77.5 \%$ of the pregnant women were between 18 and 30 years old and their prenatal attachment scores were significantly higher than other age groups. Similarly, Bakır et al. ${ }^{[2]}$ found that mean prenatal attachment scores of the pregnant women, 55.6\% of which were in the same age group (18-30) were higher at a statistically significant level than the advanced age group. In the study of Yilmaz and Beji ${ }^{[3]}$ the authors reported that prenatal attachment level of the pregnant women in the age group of 18-34 was significantly higher than those who are 35 years old and above. Literature findings also support the results of our study. There are also other studies showing that there is an inverse correlation between maternal age and prenatal attachment. ${ }^{[12,14,15]}$ This result can be interpreted by the fact that expectant mothers from younger age groups are ready to have children.

Alan Dikmen and Çankaya ${ }^{[9]}$ found in their study that the prenatal attachment level of pregnant women with elementary family type is significantly higher than those with extended or fragmented family type. On the other hand, Kartal and Karaman ${ }^{[16]}$ reported in their study, entitled "The impact of childbirth classes on prenatal attachment and depression risk in pregnant women", that the prenatal attachment scores of pregnant women with extended family types are higher than those with elementary family type. Although we found higher PAI scores in elementary and extended family types compared to the fragmented family type in our study, the correlation between them was not significant. This situation which is different than the literature may be associated with the characteristics of study groups.

It is stated in the literature that having problem during pregnancy affects prenatal attachment process negatively. ${ }^{[2,912]}$ Having problem during pregnancy, or risky pregnancy in other words, affects partner compatibility negatively, increases stress level during prenatal period and even leads up to postpartum depression. Therefore, it is indicated that having stress during pregnancy is a risk factor for postpartum depression. ${ }^{[17,18]}$

In our study, we found significantly higher mean PDS scores in those who had problems during pregnancy than those who did not have any problem. While mean PDS scores of pregnant women who are always compatible with their partners were significantly lower than other groups, their mean PAI scores were higher. Our study result is consistent with the literature.

Öztürk ${ }^{[19]}$ reported in their study, entitled "The impact of perceived social support on prenatal attachment and anxiety experienced during pregnancy", that mean PAI scores of pregnant women who received social and family support were significantly higher. Although we did not find any significant correlation between family support and mean PAI scores, mean PAI scores of the group which receive family support 
were higher. We had a similar result related with the number of children. Although it was not statistically significant, PDS scores of primiparous pregnant women were higher than the groups with 1-2 children and more than 3 children. Çapik et al. ${ }^{[20]}$ reported in their study that there was a significant correlation between the number of children and mean PDS scores in favor of primiparous pregnant women.

\section{Conclusion}

In conclusion, mean prenatal attachment inventory scores were higher $(62.35 \pm 11.28)$ and mean prenatal distress scale scores were slightly lower than moderate level (10.26 \pm 5.18$)$. There was a negatively week correlation between the mean scores of prenatal distress and prenatal attachment scales. Accordingly, prenatal attachment levels of pregnant women significantly decreased as their stress levels increased. We found that age, number of children, the status of planning pregnancy, partner compatibility and having problem during pregnancy affected prenatal distress level and therefore prenatal attachment.

Conflicts of Interest: No conflicts declared.

\section{References}

1. Erkal Aksoy Y, Dereli Yılmaz S, Aslantekin F. Riskli gebelerde prenatal bağlanma ve sosyal destek. Türkiye Klinikleri Journal of Health Sciences 2016;1:163-9.

2. Bakır N, Ölçer Z, Oskay Ü. Yüksek riskli gebelerin prenatal bağlanma düzeyi ve etkileyen faktörler. Uluslararası Hakemli Kadın Hastalıkları ve Anne Çocuk Sağlığı Dergisi (JACSD) 2014;1:25-37.

3. Yılmaz SD, Beji NK. Gebelerin stresle başa çıkma, depresyon ve prenatal bağlanma düzeyleri ve bunları etkileyen faktörler Genel Tip Dergisi 2010;20:100-8.

4. Özorhan EY, Ejder Apay S, Düzyurt M. Riskli olan ve olmayan gebelerin prenatal bağlanma düzeylerinin karşılaştırılması. Uluslararası Hakemli Kadın Hastalıkları ve Anne Çocuk Să̆lığ1 Dergisi (JACSD) 2015;3:1-15.

5. Özkan A, Arslan H. Gebeliğe karar verme, fizyolojik yakınmaları algılama ve eğitim gereksinimleri. Zeynep Kamil Tıp Bülteni 2007;38:155-61.

6. Uçar H. Gebelerin psikososyal sağlık durumları ile annelik rolü arasındaki ilişki. Yüksek lisans tezi, Atatürk Üniversitesi Sağlık Bilimleri Enstitüsü, Erzurum, 2014.
7. Babacan Gümüş A, Çevik N, Hataf Hyusni S, Biçen Ş, Keskin G, Tuna Malak A. Gebelikte benlik saygısı ve beden imajı ile ilişkili özellikler. Anatolian Journal of Clinical Investigation 2011;5:7-14.

8. Hacettepe Üniversitesi Nüfus Etüdleri Enstitüsü. Türkiye Nüfus ve Sağlık Araştırması (TNSA) 2013. Retrieved from: www.hips.hacettepe.edu.tr/tnsa2013/rapor/TNSA_2013_ana _rapor.pdf

9. Alan Dikmen H, Çankaya S. Maternal obezitenin prenatal bağlanma üzerine etkisi. Acıbadem Üniversitesi Sağlık Bilimleri Dergisi 2018;9:118-23.

10. Altınçelep F. Gebelerdeki prenatal distres düzeyinin belirlenmesi. Yüksek lisans tezi, İstanbul Bilim Üniversitesi Sağl1k Bilimleri Enstitüsü, İstanbul, 2011.

11. Yüksel F, Akın S, Durna Z. Prenatal distres ölçeğinin Türkçe'ye uyarlanması ve faktör analizi. Hemşirelikte Eğitim ve Araşturma Dergisi 2011;8:43-51.

12. Abasi E, Tahmasebi H, Zafari M, Nairi Takami G. Assessment on effective factors of maternal-fetal attachment in pregnant women. Life Science Journal 2012;9:68-75.

13. Topaç Tunçel N, Kahyaoğlu Süt H. Gebelikte yaşanan anksiyete, depresyon ve prenatal distres düzeyinin doğum öncesi bebeğe bağlanmaya etkisi. Jinekoloji - Obstetrik ve Neonatoloji Tip Dergisi 2019;16:9-17.

14. Elkin N. Gebelerin prenatal bağlanma düzeyleri ve bunları etkileyen faktörler. Sürekli Tip Eğitimi Dergisi 2015;24:230-6.

15. Lindgren K. Relationships among maternal-fetal attachment, prenatal depression, and health practices in pregnancy. Res Nurs Health 2001;24:203-17.

16. Kartal YA, Karaman T. Doğuma hazırlık eğitiminin gebelerde prenatal bağlanma ve depresyon riski üzerine. Zeynep Kamil Tip Bülteni 2018;49:85-91.

17. Çobanlar Akkaş S. Gebelik döneminde eşler arası uyum. Yüksek lisans tezi, Aydın Adnan Menderes Üniversitesi Sağlık Bilimleri Enstitüsü, Aydın, 2014.

18. Ayvaz S, Hocaoğlu Ç, Tiryaki A, Ak İ. Incidence of postpartum depression in Trabzon province and risk factors at gestation. [Article in Turkish] Turk Psikiyatri Derg 2006;17:24351.

19. Öztürk E. Algılanan sosyal desteğin prenatal bağlanma ve gebelikte yaşanan anksiyete üzerine etkisi. Yüksek lisans tezi, Manisa Celal Bayar Üniversitesi Sağlık Bilimleri Enstitüsü, Manisa, 2018.

20. Çapık A, Ejder Apay S, Sakar T. Gebelerde distres düzeyinin belirlenmesi. Anadolu Hemşirelik ve Sağlık Bilimleri Dergisi 2015;18:196-203.

Bu makalenin kullanım izni Creative Commons Attribution-NoCommercial-NoDerivs 3.0 Unported (CC BY-NC-ND3.0) lisansı aracılı̆̆ıyla bedelsiz sunulmaktadir. / This work is licensed under the Creative Commons Attribution-NonCommercial-NoDerivs 3.0 Unported (CC BY-NC-ND3.0) License. To view a copy of this license, visit http://creativecommons.org/licenses/by-nc-nd/3.0/ or send a letter to Creative Commons, PO Box 1866, Mountain View, CA 94042, USA. 